Article

\title{
Optimization of Regioselective $\alpha$-Glucosylation of Hesperetin Catalyzed by Cyclodextrin Glucanotransferase
}

\author{
José L. González-Alfonso ${ }^{1}{ }^{\circledR}$, Noa Míguez ${ }^{1}$, J. Daniel Padilla ${ }^{2}$, Laura Leemans ${ }^{1}$, Ana Poveda ${ }^{3}$, \\ Jesús Jiménez-Barbero ${ }^{3}$, Antonio O. Ballesteros ${ }^{1}$, Georgina Sandoval ${ }^{1,2}$ \\ and Francisco J. Plou 1,*(D) \\ 1 Instituto de Catálisis y Petroleoquímica, CSIC, 28049 Madrid, Spain; josel.g@csic.es (J.L.G.-A.); \\ noa.miguez@csic.es (N.M.); lauraleetin@gmail.com (L.L.); a.ballesteros@icp.csic.es (A.O.B.); \\ gsandoval@ciatej.mx (G.S.) \\ 2 Centro de Investigación y Asistencia en Tecnología y Diseño del Estado de Jalisco (CIATEJ), \\ Guadalajara 44270, Jalisco, Mexico; jdpadilla@ciatej.mx \\ 3 Center for Cooperative Research in Biosciences, Parque Científico Tecnológico de Bizkaia, \\ 48160 Derio, Biscay, Spain; apoveda@cicbiogune.es (A.P.); jjbarbero@cicbiogune.es (J.J.-B.) \\ * Correspondence: fplou@icp.csic.es; Tel.: +34-91-585-4869
}

Received: 17 October 2018; Accepted: 1 November 2018; Published: 5 November 2018

check for updates

\begin{abstract}
The regioselective $\alpha$-glucosylation of hesperetin was achieved by a transglycosylation reaction catalyzed by cyclodextrin glucanotransferase (CGTase) from Thermoanaerobacter sp. using soluble starch as glucosyl donor. By combining mass spectrometry (ESI-TOF) and 2D-NMR analysis, the main monoglucosylated derivative was fully characterized (hesperetin $7-O-\alpha$-D-glucopyranoside). In order to increase the yield of monoglucoside, several reaction parameters were optimized: Nature and percentage of cosolvent, composition of the aqueous phase, glucosyl donor, temperature, and the concentrations of hesperetin and soluble starch. Under the optimal conditions, which included the presence of $30 \%$ of bis(2-methoxyethyl) ether as cosolvent, the maximum concentration of monoglucoside was approximately $2 \mathrm{mM}$, obtained after $24 \mathrm{~h}$ of reaction. To our knowledge, this is the first report of direct glucosylation of hesperetin employing free enzymes instead of whole cells.
\end{abstract}

Keywords: polyphenols; glycosylation; flavonoids; flavanones; cyclodextrin glucosyltransferase; enzymatic glucosylation; hesperidin; hesperetin

\section{Introduction}

Dietary flavonoids (formerly called vitamin P) exhibit an ample range of biological activities, including antimicrobial, antihypertensive, antitumoral, neuroprotective and anti-inflammatory [1-5]. Among them, hesperetin (5,7,3'-trihydroxyl-4'-methoxylflavanone), which is mostly present in citrus fruits but also in tomatoes, apples and some flowers, has obtained notable interest due to its outstanding multifunctional medicinal properties [6,7]. On the basis of its ability to promote cellular antioxidant defense, hesperetin has been demonstrated to prevent the development of some chronic diseases including various types of cancer and Alzheimer's disease [3,8-10]. Curiously, hesperetin also presents activity against parasites from tropical diseases $[6,11]$.

The hydrophobic nature of many bioflavonoids partially explains their limited absorption in vivo [12,13]. In this context, hesperetin barely dissolves in water, and this low aqueous solubility limits its further pharmacological exploitation. It is well reported that various flavonoids are glycosylated in nature and these sugar moieties play a major role in their absorption [14], bioavailability [15], 
bioactivity [16] and water solubility [17]. Glycosylation can also protect bioflavonoids from oxygen and/or light degradation, as well as during storage and gastrointestinal transit after ingestion [18].

Unfortunately, hesperidin (hesperetin 7-rutinoside), the natural glycosylated form of hesperetin, also exhibits a negligible solubility in water. Different glycosides of hesperidin have been synthesized in order to expand its biopharmaceutical applications and improve its bioavailability [19-21]. A Japanese company commercializes an $\alpha$-glucosylated derivative of hesperidin with improved performance in cosmetic preparations [22].

For glycosylation of flavonoids, the use of enzymes is a very attractive strategy due to their unique specificity and the mild conditions required for such biotransformations [23-27]. The enzymatic glycosylation of hesperetin has been scarcely investigated, and only a few reports have been published employing cultured cells from yeasts or plants. In particular, Shimoda et al. achieved the $\alpha$-glucosylation of hesperetin by the use of Xanthomonas campestris cells; the resulting monoglucosides were further enzymatically glycosylated into the corresponding maltosides [28]. In other work, the same group employed cultured cells of Ipomoea batatas and Eucalyptus perriniana to convert hesperetin into various mono- and di- $\beta$-glucosides [29]. An indirect way to obtain mono- $\beta$-glucosylated derivatives of hesperetin was developed by other authors, which relies on the controlled hydrolysis of hesperidin by $\alpha$-rhamnosidase.

In this work, we describe the enzymatic synthesis of an $\alpha$-glucosylated derivative of hesperetin by a transglycosylation reaction catalyzed by a transglycosidase, namely cyclodextrin glycosyltransferase (CGTase, EC 2.4.1.19), which employs a renewable and easily available carbohydrate (starch) as glucosyl donor [30]. In previous works, we successfully achieved the $\alpha$-glucosylation of a flavonoid (epigallocatechin gallate [26]) and two stilbenes (resveratrol [31], pterostilbene [32]) with this enzyme.

\section{Results and Discussion}

\subsection{Enzymatic Glucosylation of Hesperetin}

We screened by TLC a series of glycosidases and transglycosidases for the glycosylation of racemic $( \pm)$-hesperetin $(6 \mathrm{mg} / \mathrm{mL})$, using the corresponding sugar donors $(50 \mathrm{mg} / \mathrm{mL})$. The screening was performed at $50{ }^{\circ} \mathrm{C}$ in presence of $30 \%(\mathrm{v} / \mathrm{v})$ acetonitrile because the solubility of hesperetin in aqueous media is almost negligible. The aqueous phase was $10 \mathrm{mM}$ sodium acetate ( $\mathrm{pH}$ 5.6), an appropriate buffer for most of the glycosidic enzymes. Results were negative with most of the enzymes tested: $\beta$-galactosidases from Bacillus circulans and Aspergillus oryzae (sugar donor: Lactose); $\alpha$-glucosidases from Aspergillus niger and Xanthophyllomyces dendrorhous (sugar donor: Maltose); $\beta$-fructofuranosidases from Saccharomyces cerevisiae and X. dendrorhous (sugar donor: Sucrose). The only enzyme that gave rise to an appreciable formation of glycosylated products was cyclodextrin glucanotransferase (CGTase) from Thermoanaerobacter sp. (Toruzyme 3.0L) [30,33], employing partially hydrolyzed starch (maltodextrins with DP $\leq 60$ ) as glucosyl donor. This enzyme has demonstrated an extraordinary ability to glucosylate other mono- and polyphenolic compounds [26,31,32,34-38].

The reaction mixture was characterized in detail by HPLC coupled to mass spectrometry (Figure 1). As shown, we detected the formation of several glucosides. The mass spectrum of the main peak at $11.42 \mathrm{~min}$ is shown in the inset of Figure 1. We observed the presence of peaks at $m / z 465.16$ and 487.14 that corresponded to the $\mathrm{M}+[\mathrm{H}]^{+}$and $\mathrm{M}+[\mathrm{Na}]^{+}$ions of the hesperetin monoglucoside, respectively. Based on HPLC/MS data, we concluded that the peaks with retention times of 10.50, 11.42 and 14.85 were monoglucosides, whilst the one that eluted at $9.84 \mathrm{~min}$ was a diglucoside. It cannot be ruled out that, in the diglucoside, the second glucosyl moiety could be attached to the first glucosyl residue by $\alpha(1 \rightarrow 4)$ linkage. CGTase and related transglycosidases typically have a tendency to form homologous series of glucosylated products with increasing polymerization degree [39-41].

The main glucoside of hesperetin (peak at $11.42 \mathrm{~min}$ ) was purified by semipreparative HPLC. In order to quantify the production of this compound under different experimental conditions, 
we measured its extinction coefficient at $284 \mathrm{~nm}$ (Figure 2). Interestingly, the glucosylation altered the spectral properties of hesperetin, giving rise to a 3.5-fold reduction of the $\varepsilon_{284}$.

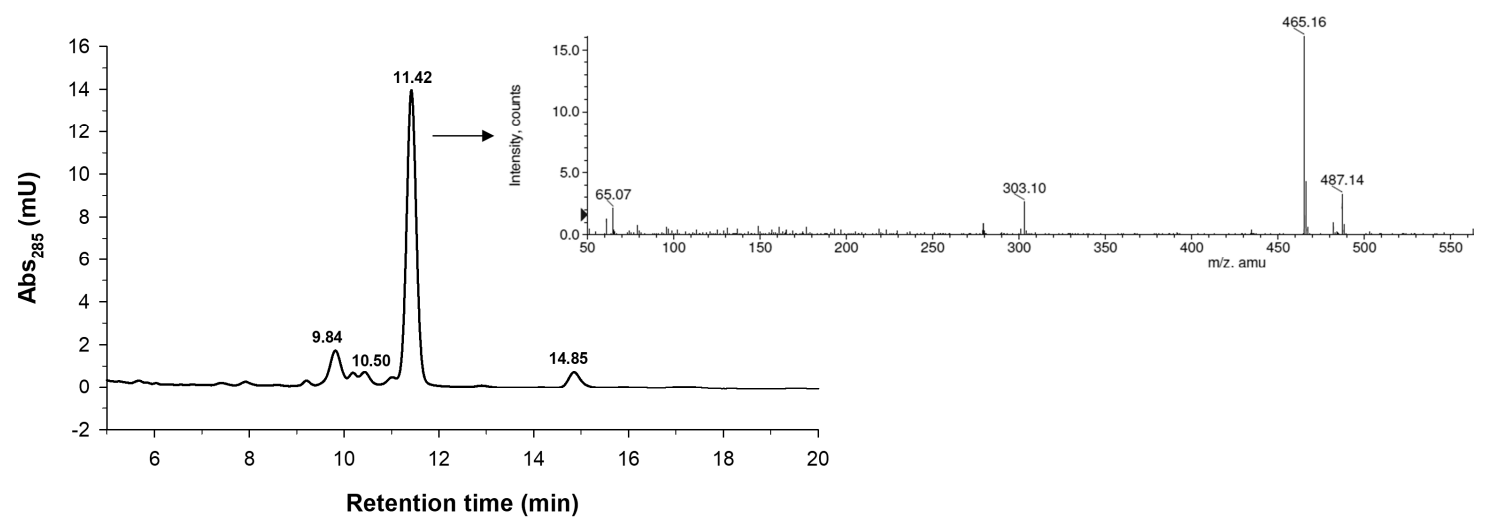

Figure 1. HPLC-MS chromatogram of the reaction mixture after $27 \mathrm{~h}$ showing the glucosides of hesperetin obtained with the CGTase from Thermoanaerobacter sp. Inset: Mass spectrum (ESI-TOF in positive mode) of the main peak at $11.42 \mathrm{~min}$. Reaction conditions: Hesperetin $(20 \mathrm{mg} / \mathrm{mL})$, soluble starch (45 mg/mL), $10 \mathrm{mM}$ sodium acetate buffer ( $\mathrm{pH} 5.6), 35 \%$ acetonitrile, CGTase from Thermoanaerobacter sp. $(5 \% \mathrm{v} / \mathrm{v}), 50{ }^{\circ} \mathrm{C}, 150 \mathrm{rpm}$.

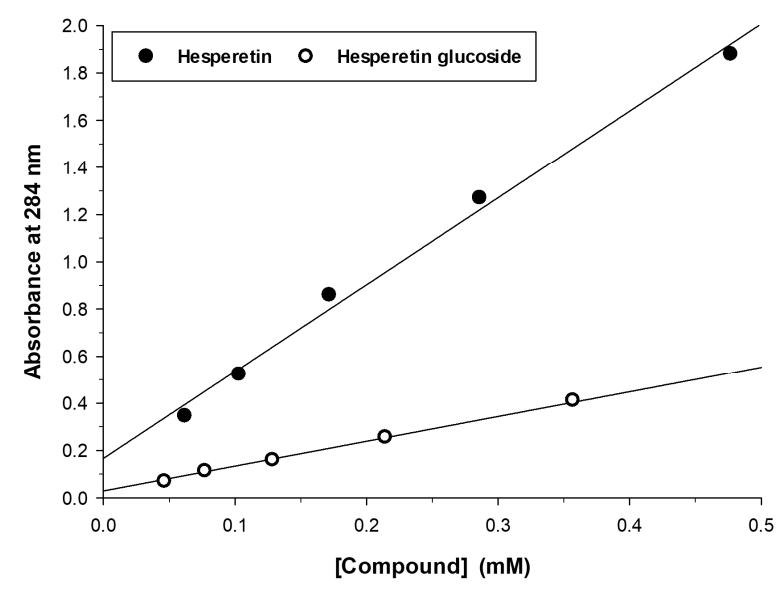

Figure 2. Absorbance at $284 \mathrm{~nm}$ vs. concentration for hesperetin and its monoglucoside.

\subsection{Characterization of the Monoglucosylated Derivative}

The high-resolution mass spectrum (HRMS) of the isolated glucoside obtained by electrospray (ESI-TOF) contained a pseudomolecular ion $[\mathrm{M}+\mathrm{Na}]^{+}$peak at $m / z 487.1217$ (Supplementary Materials, Figure S1), consistent with a molecular formula of $\mathrm{C}_{22} \mathrm{H}_{24} \mathrm{O}_{11}$ (calcd. 487.1230 for $\mathrm{C}_{22} \mathrm{H}_{24} \mathrm{NaO}_{11}$ ).

The structure of the glucosylated derivative was deduced by using 2D-NMR (see Table 1 and Figures S2-S7 of Supplementary Materials). The analysis of the NMR data permitted to show, in a non-ambiguous manner, that glucosylation of the hesperetin takes place with $\alpha$-configuration at position $\mathrm{O}-7$ of the $\mathrm{A}$ ring (Figure 3). Indeed, NOEs were observed between the anomeric $\mathrm{H} 1^{\prime}$ proton and protons $\mathrm{H} 6$ and $\mathrm{H} 8$ of A ring. The $\alpha$-configuration was deduced from the sugar ${ }^{3} J_{\mathrm{H} 1-\mathrm{H} 2}$ coupling value of $3.4 \mathrm{~Hz}$. In addition, a correlation HMBC peak was observed between the same $\mathrm{H} 1^{\prime}$ proton and C7 of A ring. The NMR spectroscopic data for hesperetin $7^{\prime}-O-\alpha-D$-glucopyranoside is summarized in Table 1. These results fit well with the data reported by Li et al. who isolated hesperetin 7-O- $\alpha$-D-glucopyranoside from the peel of citrus species [42]. Since the starting material is racemic [( \pm -hesperetin], the final monoglucosylated product is a 50/50 mixture of diastereoisomers, due to the presence of epimers at carbon C-2. Thus, several signals appeared duplicated in the spectra. 
The synthesis of this compound was previously reported by Shimoda et al. using Xanthomonas campestris cells [28], who obtained a mixture of $3^{\prime}-$, 5- and 7-O- $\alpha$-D-glucosides. However, no spectroscopy data of such compounds are available in that work. Other articles dealing with glucosylation of hesperetin described the formation of $\beta$-glucosides, employing plant cultured cells of Ipomoea batatas and Eucalyptus perriniana [29], and Citrus paradisi [43]. To our knowledge, our present work describes for the first time the glucosylation of hesperetin employing free enzymes instead of whole cells.

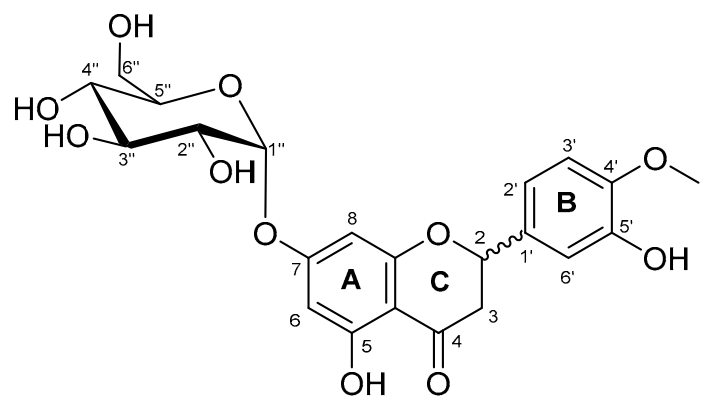

Figure 3. Chemical structure of hesperetin 7-O- $\alpha$-D-glucopyranoside.

Table 1. NMR Spectroscopic Data $\left(600 \mathrm{MHz}, \mathrm{DMSO}-d_{6}\right)$ for hesperetin 7-O- $\alpha$-D-glucopyranoside. Data obtained from HSQC and HMBC spectra.

\begin{tabular}{|c|c|c|}
\hline Position & $\delta_{H}$ & $\delta_{C}$ \\
\hline 2 & 5.48 & 78.2 \\
\hline 3 & $2.8,3.3$ & 42.1 \\
\hline 4 & - & 196.8 \\
\hline $5^{a}$ & - & 162.6 \\
\hline $6^{b}$ & $6.2^{c}$ & 95.6 \\
\hline 7 & - & 164.7 \\
\hline $8^{b}$ & 6.18 & 96.5 \\
\hline $9^{a}$ & - & 162.2 \\
\hline 10 & - & 103.0 \\
\hline $1^{\prime}$ & - & 130.5 \\
\hline $2^{\prime}$ & $6.9^{c}$ & 117.5 \\
\hline $3^{\prime}$ & 6.9 & 111.7 \\
\hline $4^{\prime}$ & - & 147.6 \\
\hline $5^{\prime}$ & - & 146.1 \\
\hline $6^{\prime}$ & 6.9 & 113.8 \\
\hline $\mathrm{MeO}$ & 3.8 & 55.4 \\
\hline $1^{\prime \prime}$ & $5.50,5.53(J=3.4 \mathrm{~Hz})^{\mathrm{c}}$ & 96.7 \\
\hline $2^{\prime \prime}$ & 3.4 & 71 \\
\hline $3^{\prime \prime}$ & 3.6 & 72.7 \\
\hline $4^{\prime \prime}$ & 3.2 & 69.4 \\
\hline $5^{\prime \prime}$ & 3.3 & 73.9 \\
\hline $6^{\prime \prime}$ & $3.54,3.46$ & 60.2 \\
\hline $\mathrm{OH} 2^{\prime \prime}$ & $5.1^{\mathrm{c}}$ & - \\
\hline $\mathrm{OH}^{\prime \prime}$ & 4.97 & - \\
\hline $\mathrm{OH} 4^{\prime \prime}$ & 5.0 & - \\
\hline $\mathrm{OH}^{\prime \prime}$ & 4.5 & - \\
\hline
\end{tabular}

${ }^{\text {a }}$ These ${ }^{13} \mathrm{C}$ assignations can be interchanged; ${ }^{\mathrm{b}}$ These ${ }^{1} \mathrm{H}$ and ${ }^{13} \mathrm{C}$ assignations can be interchanged; ${ }^{\mathrm{c}}$ Duplicated signals due to the presence of diasteroisomers.

\subsection{Optimization of Hesperetin Glucosylation}

Several reaction parameters were assessed in order to increase the yield of the hesperetin monoglucoside. First, the effect of the nature of the organic cosolvent was studied fixing the organic solvent concentration at $30 \% v / v$. Figure 4 a represents the concentration of the $7^{\prime}-O-\alpha$-D-glucoside 
after $18 \mathrm{~h}$ reaction. As shown, bis(2-methoxyethyl) ether (diglyme) and acetonitrile gave rise to the highest production levels of the monoglucoside. No reaction was observed in absence of cosolvent and it was very slow in the case of THF. Then, we varied the percentage of diglyme in the range $20-40 \%$. As illustrated in Figure $4 b, 30 \% v / v$ was the optimum value. It is likely that increasing the cosolvent percentage above $30 \%$ could cause certain inactivation of CGTase, despite the enhancement of hesperetin solubility.
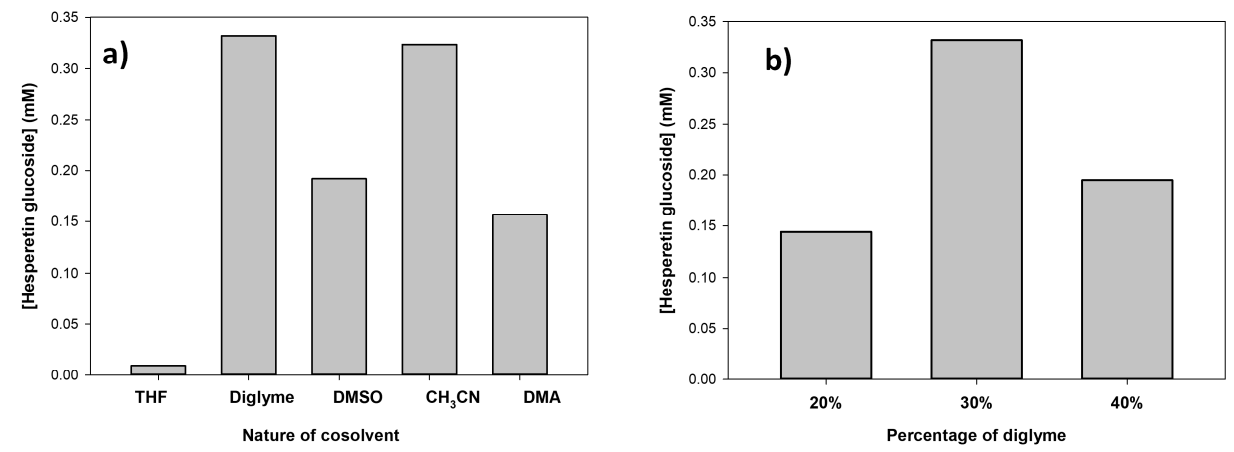

Figure 4. (a) Effect of different cosolvents at $30 \%(v / v)$ on the glucosylation of hesperetin. (b) Effect of the concentration of bis(2-methoxyethyl) ether. Reaction conditions: hesperetin $(6 \mathrm{mg} / \mathrm{mL})$, partially hydrolyzed starch $(50 \mathrm{mg} / \mathrm{mL})$, CGTase from Thermoanaerobacter sp. $(10 \% v / v), 10 \mathrm{mM}$ acetate buffer $\mathrm{pH} 5.6(50-70 \%)$, organic solvent $(20-40 \%), 50{ }^{\circ} \mathrm{C}, 1000 \mathrm{rpm}$. The reactions were analyzed after $18 \mathrm{~h}$ by HPLC as described.

The transglycosylation activity of CGTase can be displayed by coupling or disproportionation reactions, which utilize cyclodextrins or maltodextrins, respectively, as glucosyl donors [44,45]. We compared the formation of hesperidin glucoside using $\alpha-C D$ or $\gamma-C D$ (coupling activity) and soluble starch (disproportionation activity) as glucosyl donors using 30\% $v / v$ diglyme as cosolvent. We concluded that partially hydrolyzed starch was the most efficient donor (data not shown).

We also analyzed the effect of the composition of the aqueous phase; we assessed different buffers (10 mM sodium citrate $\mathrm{pH}$ 5.0, $10 \mathrm{mM}$ sodium acetate $\mathrm{pH}$ 5.6) and water. Citrate buffer $\mathrm{pH} 5.0$ gave rise to the highest yield of monoglucoside (data not shown).

Then, we studied the effect of temperature on the reaction course. Figure 5 represents the formation of hesperetin monoglucoside at different temperatures $\left(50-80^{\circ} \mathrm{C}\right)$ after $18 \mathrm{~h}$. As illustrated, $60{ }^{\circ} \mathrm{C}$ was the optimum temperature, in accordance with other biotransformations catalyzed by this enzyme $[39,46]$, since this temperature represents a compromise between enzyme activity and protein stability.

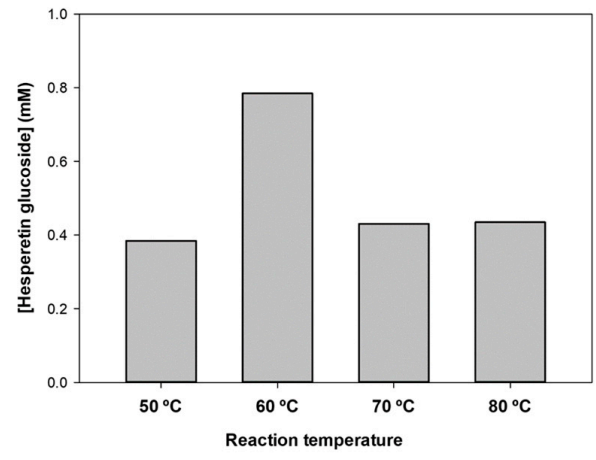

Figure 5. Effect of temperature on the glucosylation of hesperetin. Reaction conditions: hesperetin $(6 \mathrm{mg} / \mathrm{mL})$, soluble starch $(50 \mathrm{mg} / \mathrm{mL})$, CGTase from Thermoanaerobacter $\mathrm{sp}$. $(10 \% \mathrm{v} / \mathrm{v})$, sodium citrate $10 \mathrm{mM}$ at $\mathrm{pH} 5.0(60 \% v / v)$, bis(2-methoxyethyl) ether $(30 \% v / v), 1000 \mathrm{rpm}$. The reactions were analyzed after $18 \mathrm{~h}$. 
The ratio glucosyl donor: acceptor is a critical point in enzyme-catalyzed transglycosylations. First, we varied the concentrations of soluble starch and hesperetin but maintaining a ratio 20:1 w/w between them (Figure 6a). As shown, the higher the concentration of hesperetin and starch, the higher the amount of glucoside synthesized. In a second step, we fixed the concentration of soluble starch $(180 \mathrm{mg} / \mathrm{mL})$ and varied the concentration of hesperetin in the range $5-20 \mathrm{mg} / \mathrm{mL}$ (Figure $6 \mathrm{~b}$ ). The maximum yield of glucoside after $18 \mathrm{~h}$ reaction $(1.8 \mathrm{mM})$ was obtained using $15 \mathrm{mg} / \mathrm{mL}$ hesperetin, which corresponded to a ratio 12:1 w/w starch/hesperetin.
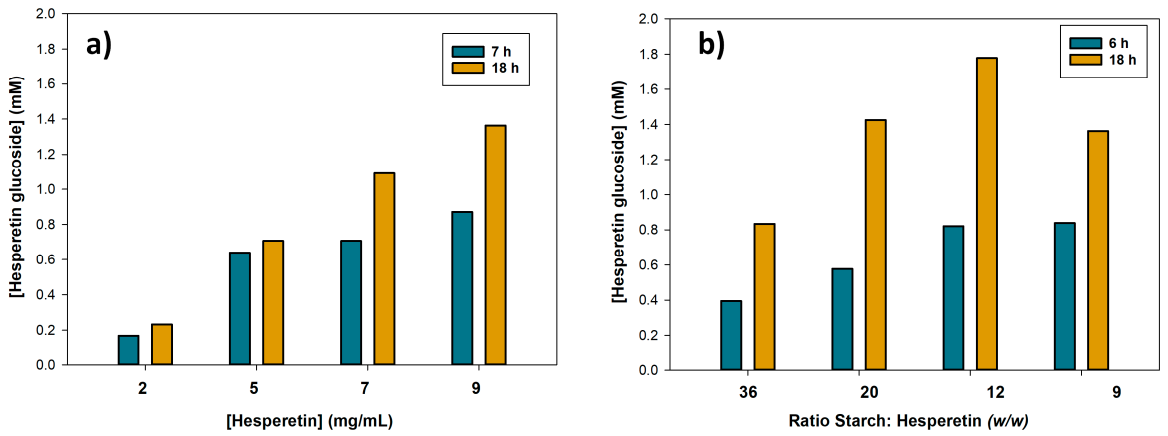

Figure 6. Effect of the concentrations of soluble starch and hesperetin on the glucosylation. (a) Maintaining a ratio 20:1 w/w starch/hesperetin; (b) Fixing the concentration of partially hydrolyzed starch $(180 \mathrm{mg} / \mathrm{mL})$ and varying the amount of hesperetin. Reaction conditions: hesperetin (2-20 mg/mL), soluble starch $(24-180 \mathrm{mg} / \mathrm{mL})$, CGTase from Thermoanaerobacter $\mathrm{sp} .(10 \% v / v)$, bis(2-methoxyethyl) ether (30\% v/v), $10 \mathrm{mM}$ sodium citrate buffer $\mathrm{pH} 5.0(60 \% \mathrm{v} / v), 60{ }^{\circ} \mathrm{C}, 1000 \mathrm{rpm}$.

\subsection{Progress of Hesperetin Glucosylation under Optimal Conditions.}

We analyzed in detail the formation of hesperetin 7-O- $\alpha$-D-glucopyranoside under the optimal conditions described before (Figure 7). As shown, the maximum concentration of monoglucoside was approximately $2 \mathrm{mM}$, obtained at $24 \mathrm{~h}$ reaction. Taking into account that the initial concentration of hesperetin was $49 \mathrm{mM}$ (although the actual value was significantly much lower because most of the hesperetin remained in solid form, even in the presence of 30\% v/v diglyme), the conversion yield was close to $4.1 \%$. Shimoda et al. reported yields between $10-15 \%$ of the $3^{\prime}-, 5$ - and $7-O-\alpha$-D-glucosides [28]; however, they employed a concentration of hesperetin of $0.02 \mathrm{mM}, 2500$-fold lower than the used in the present work. In addition, the enzymatic process carried out with CGTase is more regioselective than that mentioned before. In addition, the $\beta$-glucosylation of hesperetin catalyzed by plant cells also takes place with low selectivity [29,43].

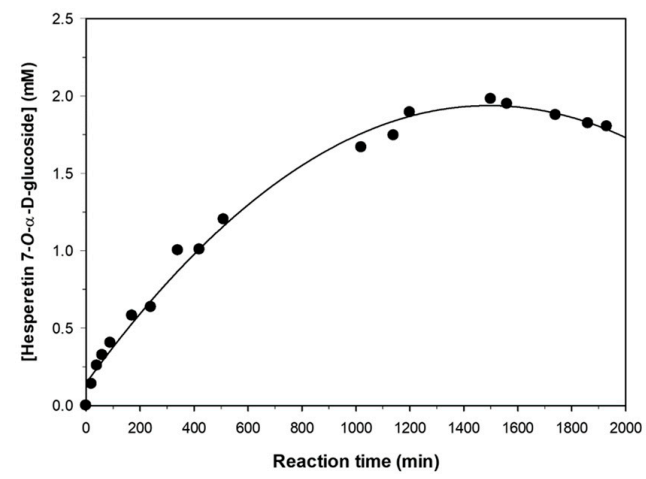

Figure 7. Progress of hesperetin glucosylation catalyzed by CGTase from Thermoanaerobacter sp. under the optimal conditions: hesperetin $(15 \mathrm{mg} / \mathrm{mL})$, soluble starch $(180 \mathrm{mg} / \mathrm{mL})$, CGTase $(10 \% v / v)$, bis(2-methoxyethyl) ether $(30 \% v / v), 10 \mathrm{mM}$ sodium citrate buffer $\mathrm{pH} 5.0(60 \% v / v), 60{ }^{\circ} \mathrm{C}, 1000 \mathrm{rpm}$. 
After the point of maximum concentration (Figure 7), the monoglucoside was slowly hydrolyzed by the action of CGTase. This behavior is typically observed in kinetically-controlled transglycosylations catalyzed by glycosidic enzymes [47-49].

\section{Materials and Methods}

\subsection{Chemicals}

$( \pm)$-Hesperetin was from Sigma-Aldrich. Partially hydrolyzed starch from potato (Paselli SA2) was from Avebe (Foxhol, The Netherlands). All other reagents and solvents were of the highest available purity and used as purchased.

\subsection{Enzymes}

The cyclodextrin glucanotransferase (CGTase) from Thermoanaerobacter sp. (Toruzyme 3.0 L) was kindly provided by Novozymes A/S. Toruzyme 3.0 L was partially purified by a PD-10 desalting column (GE Healthcare, Chicago, IL, USA).

\subsection{Optimal Conditions for Enzymatic Glucosylation of Hesperetin}

Hesperetin $(15 \mathrm{mg})$ and partially hydrolyzed starch $(180 \mathrm{mg})$ were dissolved in a mixture of $10 \mathrm{mM}$ sodium citrate buffer $\mathrm{pH} 5.0(0.6 \mathrm{~mL})$ and bis(2-methoxyethyl) ether $(0.3 \mathrm{~mL})$. Partially purified CGTase from Thermoanaerobacter sp. $(0.1 \mathrm{~mL})$ was then added to a final concentration of $10 \% v / v$. The mixture was maintained at $60^{\circ} \mathrm{C}$ in an orbital shaker (model SI50, Stuart Scientific, Staffordshire, $\mathrm{UK})$ at $1000 \mathrm{rpm}$. Aliquots $(150 \mu \mathrm{L})$ were withdrawn at intervals, diluted with $150 \mu \mathrm{L}$ of acetonitrile to stop the reaction, passed through $0.45 \mu \mathrm{m}$ nylon filters (Cosela, Sevilla, Spain) and analyzed by HPLC.

\subsection{High-Performance Liquid Chromatography (HPLC)}

HPLC analysis was performed using a quaternary pump (model 600, Waters, Milford, MA, USA) coupled to an autosampler (Varian ProStar, Palo Alto, CA, USA, model 420). The column was ACE 3 C18-PFP (4.6 $\times 150 \mathrm{~mm}$, Symta, Madrid, Spain). The temperature of the column was kept constant at $40{ }^{\circ} \mathrm{C}$. The injection volume was $20 \mu \mathrm{L}$. The detection of peaks was carried out using a photodiode array detector (ProStar, Varian, Palo Alto, CA, USA) and peaks were analyzed using the Varian Star LC workstation 6.41. Quantification was performed at $284 \mathrm{~nm}$. The mobile phase was acetonitrile/water $60: 40(v / v)$ at $0.7 \mathrm{~mL} / \mathrm{min}$ during $25 \mathrm{~min}$. Both solvents contained $0.1 \%(v / v)$ of formic acid.

\subsection{HPLC coupled to Mass Spectrometry (HPLC-MS)}

The molecular weight of reaction products was determined by HPLC-MS using a HPLC 1100 (Agilent Technologies, Santa Clara, CA, USA) equipped with a photodiode array detector and coupled to mass spectrometer (Maxis II, Bruker, Billerica, MA, USA) with hybrid QTOF analyzer. Samples were ionized by electrospray (with nitrogen to desolvate the mobile phase) and analyzed in positive reflector mode. The analysis was performed with an ACE C18-PFP column $(4.6 \times 100 \mathrm{~mm}$, Symta, Madrid, Spain). The mobile phase was $\mathrm{MeOH} / \mathrm{H}_{2} \mathrm{O} 48: 52(v / v)$. Both solvents contained $0.1 \%(v / v)$ of formic acid. The flow rate was $0.7 \mathrm{~mL} / \mathrm{min}$, and the column temperature was kept constant at $40{ }^{\circ} \mathrm{C}$.

\subsection{Purification of the Main Hesperetin Glucoside}

The glucosylation of hesperetin was scaled up. The reaction mixture contained hesperetin $(180 \mathrm{mg})$, soluble starch $(3.6 \mathrm{~g})$, Toruzyme $3.0 \mathrm{~L}(2 \mathrm{~mL}), 14 \mathrm{~mL}$ of $10 \mathrm{mM}$ sodium citrate buffer $\mathrm{pH} 5.0$ and $6 \mathrm{~mL}$ of bis(2-methoxyethyl) ether. The mixture was incubated for $24 \mathrm{~h}$ at $60{ }^{\circ} \mathrm{C}$ with orbital shaking (model SI50, Stuart Scientific, Staffordshire, UK) at $150 \mathrm{rpm}$. The mixture was then cooled and concentrated, and the glucosylated derivatives of hesperetin were purified using semipreparative HPLC. The column was ACE 5 C18-PFP $(10 \times 250 \mathrm{~mm}$, Symta). A three-way flow splitter at $1 / 10$ (Accurate, LC Packings, SpectraLab, Ontario, ON, Canada) was employed. The starting mobile phase was $\mathrm{MeOH} /$ water 
50:50 $(v / v)$ and the gradient is described in Table 2. Both solvents contained $0.1 \%(v / v)$ of formic acid. The flow rate was $4.6 \mathrm{~mL} / \mathrm{min}$, and the column temperature was kept constant at $40^{\circ} \mathrm{C}$. After collecting the glucosylated products, the mobile phase was eliminated by rotatory evaporation in an R-210 rotavapor (Buchi, Essen, Germany). The isolated products were characterized by mass spectroscopy and NMR.

Table 2. HPLC gradient profile for purification of hesperetin monoglucoside.

\begin{tabular}{ccc}
\hline Time & Methanol (\%) & Water (\%) \\
\hline $0-2$ min & 50 & 50 \\
$2-5$ min & 52 & 48 \\
$5-10 \mathrm{~min}$ & 55 & 45 \\
$10-20 \mathrm{~min}$ & 60 & 40 \\
$20-30 \mathrm{~min}$ & 70 & 30 \\
\hline
\end{tabular}

\subsection{Mass Spectrometry (MS)}

The HRMS of purified hesperetin monoglucoside was assessed using a mass spectrometer with hybrid QTOF analyzer (model QSTAR, Pulsar i, AB Sciex, Madrid, Spain). The sample was analyzed

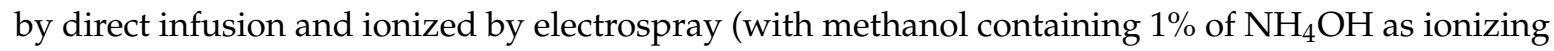
phase) in positive reflector mode.

\subsection{Nuclear Magnetic Resonance (NMR)}

The structure of the monoglucosylated hesperetin derivative was determined using a combination of 1D and 2D (COSY, DEPT-HSQC, NOESY) standard NMR techniques. The spectra of the sample, dissolved in DMSO- $d_{6}$ (ca. $7 \mathrm{mM}$ ), were recorded on a Bruker IVDr 600 spectrometer equipped with a BBI probe with gradients in the $Z$ axis, at a temperature of $300 \mathrm{~K}$. Chemical shifts were expressed in parts per million (ppm). Residual DMSO- $d_{5}$ signal was used as internal reference ( $\left.2.5 \mathrm{ppm}\right)$. All the employed pulse sequences were provided by Bruker. For the DEPT-HSQC experiment, values of $8 \mathrm{ppm}$ and $1 \mathrm{~K}$ points, for the ${ }^{1} \mathrm{H}$ dimension, and $165 \mathrm{ppm}$ and 256 points for the ${ }^{13} \mathrm{C}$ dimension, were used. For the homonuclear COSY and NOESY experiments, 8 ppm windows were used with a $1 \mathrm{~K} \times 256$ point matrix. For the NOESY the mixing time was $500 \mathrm{~ms}$.

\section{Conclusions}

We report for the first time a regioselective enzymatic process for the glucosylation of hesperetin. The glucosyl moiety is attached to the flavonoid in $\alpha$-configuration. Previous works of hesperetin glycosylation were carried out with whole cells and, except in one case [28], the resulting products were $\beta$-glucosides. Glycosylation of hesperetin has been also achieved by hesperidin hydrolysis catalyzed by $\alpha$-rhamnosidases [50], but in this case the glucosides present $\beta$-configuration. We demonstrated in a previous work on glucosylation of resveratrol that the anomeric configuration of the linked glucose exerts a substantial effect on the physico-chemical and surfactant properties of the synthesized products [31]. The synthesized monoglucoside could be of interest in the nutraceutical, cosmetic and pharmaceutical industries, as occurs with hesperidin glucosides [51]. Nevertheless, further studies on its bioavailability and bioactivity are necessary to estimate its full potential [52].

Supplementary Materials: The following figures are available online, Figure S1: HRMS spectrum for hesperetin $7^{\prime}$-O- $\alpha$-D-glucopyranoside; Figure S2: NMR Spectra $\left(600 \mathrm{MHz}, \mathrm{DMSO}-d_{6}, 298 \mathrm{~K}\right)$ for hesperetin and its $4^{\prime}$-O- $\alpha$-D-glucopyranoside; Figure S3: ${ }^{1} \mathrm{H}-{ }^{13} \mathrm{C}$ HSQC edited NMR Spectrum $\left(600 \mathrm{MHz}, \mathrm{DMSO}-d_{6}, 298 \mathrm{~K}\right)$ for hesperetin $7^{\prime}-O-\alpha$-D-glucopyranoside; Figure S4: COSY NMR Spectrum (600 MHz, DMSO- $\left.d_{6}, 298 \mathrm{~K}\right)$ for hesperetin 7'-O- $\alpha$-D-glucopyranoside; Figure S5: NOESY NMR Spectrum (600 MHz, DMSO- $\left.d_{6}, 298 \mathrm{~K}\right)$ for hesperetin $7^{\prime}-O-\alpha$-D-glucopyranoside; Figure S6: ${ }^{1} \mathrm{H}_{-}{ }^{13} \mathrm{C}$ HMBC NMR Spectrum $\left(600 \mathrm{MHz}, \mathrm{DMSO}-d_{6}, 298 \mathrm{~K}\right)$ for hesperetin $7^{\prime}-O$ - $\alpha$-D-glucopyranoside; Figure S7: Hesperetin (up) and hesperetin $7^{\prime}-O$ - $\alpha$-D-glucopyranoside signals affected by the diastereoisomers formation (down). 
Author Contributions: F.J.P., G.S. and A.O.B. conceived and designed the experiments; J.L.G.-A., N.M., L.L. and J.D.P. performed most of the experiments; A.P. and J.J.-B. carried out the NMR work; F.J.P. and G.S. wrote the paper, which was improved by the rest of authors.

Funding: This research was funded by the Spanish Ministry of Economy and Competitiveness (Grant BIO2016-76601-C3-1-R) and the Spanish Ministry of Education (Sabbatical grant to G.S. ref. SB2010-0004).

Acknowledgments: We thank Ramiro Martinez (Novozymes A/S) for supplying CGTase and for relevant suggestions. We thank the support of the EU COST-Action CM1303 on Systems Biocatalysis.

Conflicts of Interest: The authors declare no conflict of interest.

\section{References}

1. Gonzales, G.B.; Van Camp, J.; Vissenaekens, H.; Raes, K.; Smagghe, G.; Grootaert, C. Review on the use of cell cultures to study metabolism, transport, and accumulation of flavonoids: From mono-cultures to co-culture systems. Compr. Rev. Food Sci. Food Saf. 2015, 14, 741-754. [CrossRef]

2. Souza, P.O.D.; Bianchi, S.E.; Figueiró, F.; Heimfarth, L.; Moresco, K.S.; Gonçalves, R.M.; Hoppe, J.B.; Klein, C.P.; Salbego, C.G.; Gelain, D.P.; et al. Anticancer activity of flavonoids isolated from Achyrocline satureioides in gliomas cell lines. Toxicol. In Vitro 2018, 51, 23-33. [CrossRef] [PubMed]

3. Spagnuolo, C.; Moccia, S.; Russo, G.L. Anti-inflammatory effects of flavonoids in neurodegenerative disorders. Eur. J. Med. Chem. 2018, 153, 105-115. [CrossRef] [PubMed]

4. González-Sarrías, A.; Núñez-Sánchez, M.A.; Tomás-Barberán, F.A.; Espín, J.C. Neuroprotective effects of bioavailable polyphenol-derived metabolites against oxidative stress-induced cytotoxicity in human neuroblastoma SH-SY5Y cells. J. Agric. Food Chem. 2017, 65, 752-758. [CrossRef] [PubMed]

5. Dai, J.; Mumper, R.J. Plant phenolics: Extraction, analysis and their antioxidant and anticancer properties. Molecules 2010, 15, 7313-7352. [CrossRef] [PubMed]

6. Madeira Junior, J.V.; Nakajima, V.M.; Contesini, F.J; Teixeira, C.B.; Macedo, J.A.; Macedo, G.A. Hesperetin: Simple natural compound with multiple biological activity. In Fruit and Pomace Extracts: Biological Activity, Potential Applications and Beneficial Health Effects; Owen, J.P., Ed.; Nova Science Publishers Inc.: New York, NY, USA, 2015; pp. 107-120. ISBN 978-1-63482-510-8.

7. Liu, X.R.; Zhang, Y.; Lin, Z.Q. Advances in studies on the biological activities of hesperidin and hesperetin. Chin. J. New Drugs 2011, 20, 329-333.

8. Yu, Y.; Kong, R.; Cao, H.; Yin, Z.; Liu, J.; Nan, X.; Phan, A.T.; Ding, T.; Zhao, H.; Wong, S.T.C. Two birds, one stone: Hesperetin alleviates chemotherapyinduced diarrhea and potentiates tumor inhibition. Oncotarget 2018, 9, 27958-27973. [CrossRef] [PubMed]

9. Li, B.; Huang, A.L.; Zhang, Y.L.; Li, Z.; Ding, H.W.; Huang, C.; Meng, X.M.; Li, J. Design, synthesis and evaluation of hesperetin derivatives as potential multifunctional anti-Alzheimer agents. Molecules 2017, 22, 1067. [CrossRef] [PubMed]

10. Devi, K.P.; Rajavel, T.; Nabavi, S.F.; Setzer, W.N.; Ahmadi, A.; Mansouri, K.; Nabavi, S.M. Hesperidin: A promising anticancer agent from nature. Ind. Crops Prod. 2015, 76, 582-589. [CrossRef]

11. Ahmadi, A.; Hassandarvish, P.; Lani, R.; Yadollahi, P.; Jokar, A.; Bakar, S.A.; Zandi, K. Inhibition of chikungunya virus replication by hesperetin and naringenin. RSC Adv. 2016, 6, 69421-69430. [CrossRef]

12. Vivekanandhan, D.K.; Verma, P.R.P.; Singh, S.K. Emerging technologies for improving bioavailability of polyphenols. Curr. Nutr. Food Sci. 2016, 12, 12-22. [CrossRef]

13. Mojzer, E.B.; Hrnčič, M.K.; Škerget, M.; Knez, Ž.; Bren, U. Polyphenols: Extraction methods, antioxidative action, bioavailability and anticarcinogenic effects. Molecules 2016, 21, 901. [CrossRef] [PubMed]

14. Vrba, J.; Kren, V.; Vacek, J.; Papouskova, B.; Ulrichova, J. Quercetin, quercetin glycosides and taxifolin differ in their ability to induce AhR activation and CYP1A1 expression in HepG2 cells. Phytother. Res. 2012, 26, 1746-1752. [CrossRef] [PubMed]

15. Makino, T.; Shimizu, R.; Kanemaru, M.; Suzuki, Y.; Moriwaki, M.; Mizukami, H. Enzymatically modified isoquercitrin, $\alpha$-oligoglucosyl quercetin 3-O-glucoside, is absorbed more easily than other quercetin glycosides or aglycone after oral administration in rats. Biol. Pharm. Bull. 2009, 32, 2034-2040. [CrossRef] [PubMed] 
16. Nieto-Domínguez, M.; de Eugenio, L.I.; Peñalver, P.; Belmonte-Reche, E.; Morales, J.C.; Poveda, A.; Jiménez-Barbero, J.; Prieto, A.; Plou, F.J; Martínez, M.J. Enzymatic Synthesis of a novel neuroprotective hydroxytyrosyl glycoside. J. Agric. Food Chem. 2017, 65, 10526-10533. [CrossRef] [PubMed]

17. Lepak, A.; Gutmann, A.; Kulmer, S.T.; Nidetzky, B. Creating a water-soluble resveratrol-based antioxidant by site-selective enzymatic glucosylation. ChemBioChem 2015, 16, 1870-1874. [CrossRef] [PubMed]

18. Raab, T.; Barron, D.; Arce Vera, F.; Crespy, V.; Oliveira, M.; Williamson, G. Catechin glucosides: Occurrence, synthesis, and stability. J. Agric. Food Chem. 2010, 58, 2138-2149. [CrossRef] [PubMed]

19. Yoshino, F.; Yoshida, A.; Toyama, T.; Wada-Takahashi, S.; Takahashi, S.S. $\alpha$-Glucosyl hesperidin suppressed the exacerbation of 5-fluorouracil-induced oral mucositis in the hamster cheek pouch. J. Funct. Foods 2016, 21, 223-231. [CrossRef]

20. Vijaya Bharathi, B.; Jaya Prakash, G.; Krishna, K.M.; Ravi Krishna, C.H.; Sivanarayana, T.; Madan, K.; Rama Raju, G.A.; Annapurna, A. Protective effect of alpha glucosyl hesperidin (G-hesperidin) on chronic vanadium induced testicular toxicity and sperm nuclear DNA damage in male Sprague Dawley rats. Andrologia 2015, 47, 568-578. [CrossRef] [PubMed]

21. Yamada, M.; Tanabe, F.; Arai, N.; Mitsuzumi, H.; Miwa, Y.; Kubota, M.; Chaen, H.; Kibata, M. Bioavailability of glucosyl hesperidin in rats. Biosci. Biotechnol. Biochem. 2006, 70, 1386-1394. [CrossRef] [PubMed]

22. Endo, S.; Mitsuzumi, H.; Uchida, S.; Maruta, K.; Ariyasu, T.; Fukuda, S.; Shimizu, R.; Takeda, R.; Shikata, C. Dietary glucosyl hesperidin improves skin color and skin conditions in women-placebo-controlled double-blind comparative study. Jpn. Pharmacol. Ther. 2015, 43, 1687-1699.

23. Desmet, T.; Soetaert, W.; Bojarová, P.; Kren, V.; Dijkhuizen, L.; Eastwick-Field, V.; Schiller, A. Enzymatic glycosylation of small molecules: Challenging substrates require tailored catalysts. Chem. Eur. J. 2012, 18, 10786-10801. [CrossRef] [PubMed]

24. Ortiz-Soto, M.E.; Seibel, J. Biotechnological synthesis and transformation of valuable sugars in the food and pharmaceutical industry. Curr. Org. Chem. 2014, 18, 964-986. [CrossRef]

25. Plou, F.J.; Gómez de Segura, A.; Ballesteros, A. Application of glycosidases and transglycosidases for the synthesis of oligosaccharides. In Industrial Enzymes: Structure, Function and Application; Polaina, J., MacCabe, A.P., Eds.; Springer: New York, NY, USA, 2007; pp. 141-157.

26. Gonzalez-Alfonso, J.L.; Leemans, L.; Poveda, A.; Jiménez-Barbero, J.; Ballesteros, A.O.; Plou, F.J. Efficient $\alpha$-glucosylation of epigallocatechin gallate catalyzed by cyclodextrin glucanotransferase from Thermoanaerobacter $\mathrm{sp}$. J. Agric. Food Chem. 2018, 66, 7402-7408. [CrossRef] [PubMed]

27. Miguez, N.; Ramirez-Escudero, M.; Gimeno-Perez, M.; Poveda, A.; Jimenez-Barbero, J.; Ballesteros, A.O.; Fernandez-Lobato, M.; Sanz-Aparicio, J.; Plou, F.J. Fructosylation of hydroxytyrosol by the $\beta$-fructofuranosidase from Xanthophyllomyces dendrorhous: Insights into the molecular basis of the enzyme specificity. ChemCatChem 2018. [CrossRef]

28. Shimoda, K.; Hamada, H. Production of hesperetin glycosides by Xanthomonas campestris and cyclodextrin glucanotransferase and their anti-allergic activities. Nutrients 2010, 2, 171-180. [CrossRef] [PubMed]

29. Shimoda, K.; Hamada, H.; Hamada, H. Glycosylation of hesperetin by plant cell cultures. Phytochemistry 2008, 69, 1135-1140. [CrossRef] [PubMed]

30. Alcalde, M.; Plou, F.J.; Andersen, C.; Martin, M.T.; Pedersen, S.; Ballesteros, A. Chemical modification of lysine side chains of cyclodextrin glycosyltransferase from Thermoanaerobacter causes a shift from cyclodextrin glycosyltransferase to alpha-amylase specificity. FEBS Lett. 1999, 445, 333-337. [CrossRef]

31. Torres, P.; Poveda, A.; Jimenez-Barbero, J.; Parra, J.L.; Comelles, F.; Ballesteros, A.O.; Plou, FJ. Enzymatic synthesis of $\alpha$-glucosides of resveratrol with surfactant activity. Adv. Synth. Catal. 2011, 353, 1077-1086. [CrossRef]

32. González-Alfonso, J.; Rodrigo-Frutos, D.; Belmonte-Reche, E.; Peñalver, P.; Poveda, A.; Jiménez-Barbero, J.; Ballesteros, A.O.; Hirose, Y.; Polaina, J.; Morales, J.; et al. Enzymatic synthesis of a novel pterostilbene $\alpha$-glucoside by the combination of cyclodextrin glucanotransferase and amyloglucosidase. Molecules 2018, 23, 1271. [CrossRef] [PubMed]

33. Uitdehaag, J.C.M.; Van Der Veen, B.A.; Dijkhuizen, L.; Dijkstra, B.W. Catalytic mechanism and product specificity of cyclodextrin glycosyltransferase, a prototypical transglycosylase from the $\alpha$-amylase family. Enzyme Microb. Technol. 2002, 30, 295-304. [CrossRef]

34. Marié, T.; Willig, G.; Teixeira, A.R.S.; Gazaneo Barboza, E.; Kotland, A.; Gratia, A.; Courot, E.; Hubert, J.; Renault, J.H.; Allais, F. Enzymatic synthesis of resveratrol $\alpha$-glycosides from $\beta$-cyclodextrin-resveratrol complex in water. ACS Sustain. Chem. Eng. 2018, 6, 5370-5380. [CrossRef] 
35. Funayama, M.; Nishino, T.; Hirota, A.; Murao, S.; Takenishi, S.; Nakano, H. Enzymatic synthesis of (+)catechin- $\alpha$-glucoside and its effect on tyrosinase activity. Biosci. Biotechnol. Biochem. 1993, 57, 1666-1669. [CrossRef]

36. Mathew, S.; Adlercreutz, P. Regioselective glycosylation of hydroquinone to $\alpha$-arbutin by cyclodextrin glucanotransferase from Thermoanaerobacter sp. Biochem. Eng. J. 2013, 79, 187-193. [CrossRef]

37. Choung, W.J.; Hwang, S.H.; Ko, D.S.; Kim, S.B.; Kim, S.H.; Jeon, S.H.; Choi, H.D.; Lim, S.S.; Shim, J.H. Enzymatic synthesis of a novel kaempferol-3-O- $\beta$-D-glucopyranosyl-( $1 \rightarrow 4)-O-\alpha$-D-glucopyranoside using cyclodextrin glucanotransferase and its inhibitory effects on aldose reductase, inflammation, and oxidative stress. J. Agric. Food Chem. 2017, 65, 2760-2767. [CrossRef] [PubMed]

38. Han, R.; Ge, B.; Jiang, M.; Xu, G.; Dong, J.; Ni, Y. High production of genistein diglucoside derivative using cyclodextrin glycosyltransferase from Paenibacillus macerans. J. Ind. Microbiol. Biotechnol. 2017, 44, 1343-1354. [CrossRef] [PubMed]

39. Martin, M.T.; Cruces, M.A.; Alcalde, M.; Plou, F.J.; Bernabe, M.; Ballesteros, A. Synthesis of maltooligosyl fructofuranosides catalyzed by immobilized cyclodextrin glucosyltransferase using starch as donor. Tetrahedron 2004, 60, 529-534. [CrossRef]

40. Plou, F.J.; Martin, M.T.; Gomez de Segura, A.; Alcalde, M.; Ballesteros, A. Glucosyltransferases acting on starch or sucrose for the synthesis of oligosaccharides. Can. J. Chem. 2002, 80, 743-752. [CrossRef]

41. Alcalde, M.; Plou, F.J.; de Segura, A.G.; Remaud-Simeon, M.; Willemot, R.M.; Monsan, P.; Ballesteros, A. Immobilization of native and dextran-free dextransucrases from Leuconostoc mesenteroides NRRL B-512F for the synthesis of glucooligosaccharides. Biotechnol. Tech. 1999, 13, 749-755. [CrossRef]

42. Li, C.; Gu, H.; Dou, H.; Zhou, L. Identification of flavanones from peel of Citrus changshan-Huyou Y. B. Chang, by HPLC-MS and NMR. Eur. Food Res. Technol. 2007, 225, 777-782. [CrossRef]

43. Lewinsohn, E.; Berman, E.; Mazur, Y.; Gressel, J. (7) Glucosylation and (1-6) rhamnosylation of exogenous flavanones by undifferentiated Citrus cell cultures. Plant Sci. 1989, 61, 23-28. [CrossRef]

44. Leemhuis, H.; Kelly, R.M.; Dijkhuizen, L. Engineering of cyclodextrin glucanotransferases and the impact for biotechnological applications. Appl. Microbiol. Biotechnol. 2010, 85, 823-835. [CrossRef] [PubMed]

45. Martin, M.T.; Alcalde, M.; Plou, F.J.; Dijkhuizen, L.; Ballesteros, A. Synthesis of malto-oligosaccharides via the acceptor reaction catalyzed by cyclodextrin glycosyltransferases. Biocatal. Biotransform. 2001, 19, 21-35. [CrossRef]

46. Strompen, S.; Miranda-Molina, A.; López-Munguía, A.; Castillo, E.; Saab-Rincón, G. Acceptor-induced modification of regioselectivity in CGTase-catalyzed glycosylations of p-nitrophenyl-glucopyranosides. Carbohydr. Res. 2015, 404, 46-54. [CrossRef] [PubMed]

47. Potocká, E.; Mastihubová, M.; Mastihuba, V. Enzymatic synthesis of tyrosol glycosides. J. Mol. Catal. B Enzym. 2015, 113, 23-28. [CrossRef]

48. Piedrabuena, D.; Míguez, N.; Poveda, A.; Plou, F.J.; Fernández-Lobato, M. Exploring the transferase activity of Ffase from Schwanniomyces occidentalis, a $\beta$-fructofuranosidase showing high fructosyl-acceptor promiscuity. Appl. Microbiol. Biotechnol. 2016, 100, 8769-8778. [CrossRef] [PubMed]

49. Linde, D.; Rodríguez-Colinas, B.; Estévez, M.; Poveda, A.; Plou, F.J.; Fernández Lobato, M. Analysis of neofructooligosaccharides production mediated by the extracellular $\beta$-fructofuranosidase from Xanthophyllomyces dendrorhous. Bioresour. Technol. 2012, 109, 123-130. [CrossRef] [PubMed]

50. Lee, Y.S.; Woo, J.B.; Ryu, S.I.; Moon, S.K.; Han, N.S.; Lee, S.B. Glucosylation of flavonol and flavanones by Bacillus cyclodextrin glucosyltransferase to enhance their solubility and stability. Food Chem. 2017, 229, 75-83. [CrossRef] [PubMed]

51. Letchmanan, K.; Shen, S.C.; Ng, W.K.; Tan, R.B.H. Application of transglycosylated stevia and hesperidin as drug carriers to enhance biopharmaceutical properties of poorly-soluble artemisinin. Colloids Surf. B 2018, 161, 83-93. [CrossRef] [PubMed]

52. Wang, P.; Sang, S. Metabolism and pharmacokinetics of resveratrol and pterostilbene. BioFactors 2018, 44, $16-25$. [CrossRef] [PubMed]

Sample Availability: Samples of the compounds are not available from the authors. 